\title{
HOLDING UP A MIRROR \\ TO APARTHEID SOUTH AFRICA: PUBLIC DISCOURSE ON THE ISSUE OF OVERCROWDING IN SOUTH AFRICAN PRISONS 1980 TO 1984 - PART 1
}

\author{
Stephen Allister Peté \\ BA LLB LLM MPhil \\ Associate Professor of Law, Faculty of Law \\ Howard College Campus \\ University of KwaZulu-Natal, Durban \\ Attorney of the High Court of South Africa
}

\section{SUMMARY}

During the first half of the 1980s, the issue of chronic overcrowding within the South African penal system formed part of an intense ideological struggle between those who supported and those who opposed the apartheid regime. Public debate around this issue acted as a mirror, reflecting early cracks which were beginning to appear in the edifice of apartheid. Since the prisons were the ultimate instrument of social control within the apartheid system, the ongoing crises caused by chronic overcrowding within these institutions served as a kind of "canary in the mine" for the apartheid system as a whole. The debates which took place during the early 1980s around overcrowding are also important because they form part of a common theme running through South African penal discourse as a whole. This article seeks to show how the debates on prison overcrowding which took place in the first half of the 1980s fit into a long term pattern of recurring ideological crises surrounding this issue.

\section{$1 \quad$ INTRODUCTION}

In many ways, the 1980 s marked a particularly tragic time in the sad history of apartheid South Africa. During these years, resistance to the apartheid system from both inside and outside the country, gained inexorably in strength. Popular protest by millions of ordinary South Africans against the system reached its peak during this period, with the United Democratic Front playing a major role in a sustained campaign of mass action against the apartheid government. As resistance to the system increased, it was met with the full might of the apartheid security apparatus, with those in power determined to resist what was termed a "total onslaught". An official "State of Emergency" was in operation for much of the decade, which was marked by 
extreme brutality, violence and repression. On the positive side, these years also marked a turning point in the struggle against apartheid, with cracks finally beginning to show in the authoritarian structure built up by the National Party government. As Nigel Worden comments:

\begin{abstract}
"The resistance of the mid-1980s destroyed utterly the 'total strategy' tactics of the Botha government. Tricameralism and African urban councils had been firmly rejected by the demand for 'People's Power'. The campaign to win hearts and minds was in tatters, with thousands in detention ... and an occupying army in the townships .... With the collapse of 'total strategy', the government seemed bankrupted of ideas, relying on internal repression and international bravado."
\end{abstract}

The focus of this article is on the first half of this crucial decade and examines only one aspect of the broad ideological struggle which was taking place in South Africa during this time - the ideological struggle waged in the mass media around the issue of overcrowding in South African prisons. It will be argued that public debate around this issue acted as kind of mirror, reflecting clearly for those who wished to see, the early cracks which were beginning to appear in the edifice of the apartheid system. Debates around the issue of prison overcrowding were only one of many ideological struggles being waged at the time, but these debates are interesting and significant for at least two reasons:

The first reason is that the debates to be examined took place at a particularly interesting time in the history of apartheid South Africa, as it was becoming increasingly clear that the stresses and strains brought about by the various measures of apartheid social-control (such as influx control and the infamous pass laws) were not sustainable and would eventually lead to the demise of the system. Since the prisons were the ultimate instruments of social control in the apartheid system, it may be argued that what was happening in the prisons during this period served as a kind of "canary in the mine" for the apartheid system as a whole. It will be contended in this article that, as alluded to in the title, public debates on the issue of prison overcrowding throughout the early 1980s held up a mirror to South African society, in which those willing to look could see reflected the inevitable demise of the apartheid system. The first task of this article is thus to illustrate the above point, by carefully tracing the public debates which took place on the issue of prison overcrowding during the period 1980 to 1984 , within the specific historical context of this period.

The second reason that public debates which took place in the early 1980s around the issue of prison overcrowding are interesting and significant, is that these debates tie in with a much broader and longer-term public and academic discourse. This discourse concerns the inextricable link which is apparent throughout South Africa's penal history, between imprisonment as a form of punishment and chronic overcrowding of prisons. This article will contend that, of all the different intertwined strands which together make up the history of public discourse surrounding imprisonment

Worden The Making of Modern South Africa - Conquest, Apartheid, Democracy 5ed (2012) 144 and 145. 
in South Africa over decades and even centuries, there is one strand which predominates. It is a strand of debate which is strongly and consistently evident across different time periods, and is apparent whether one is examining the public discourse of the colonial period, the apartheid period, or the post-apartheid period. The debate consists of an interminable series of "shock revelations" about the state of chronic overcrowding in South African prisons and the steps that must be taken to remedy the problem. What is most interesting about the many discussions and debates that have taken place over many years in the public media on the issue of chronic overcrowding in South African prisons, is the remarkable similarity of these discussions and debates. The points made and the concerns expressed have remained the same over an extraordinarily long period of time. Over and over again, year after year, the same problem was identified, the dreadful consequences of overcrowding were spelled out in lurid detail, similar reasons are put forward as to its cause, and similar solutions were proposed. The debates seem, somehow, to be stuck in a loop, destined to be repeated from year to year, decade to decade, and even from one century to the next. This article will seek to show how the debates on prison overcrowding which took place in the first half of the 1980s fit into this longterm pattern.

Part one of the article will begin by examining the effect on public discourse of the measures which were in place at the time to restrict reporting on prison conditions. In particular, the manner in which section 44(1)(f) of the Prisons Act restricted reporting in the public media will be examined. ${ }^{2}$ Following this, continuing in the same vein, evidence presented to the Steyn Commission of Enquiry into the public media will be discussed. Attention will then turn to the Hoexter Commission of Enquiry into the structure and functioning of South Africa's courts, in particular the way in which evidence before this commission led to an explosion of public debate on prison overcrowding in the early 1980s. The final section of part one of this article will examine the strong link which was evident in the public discourse of the early 1980 s, between the crises caused by overcrowding in South African prisons, and the major cracks which were becoming increasingly apparent in the edifice of the apartheid system and its measures of social control. Part two of the article will take forward certain of the themes examined in part one, in particular the clear link revealed in the public discourse between prison overcrowding and a political and economic system in crisis. The article will conclude by drawing together the main themes referred to in this introduction.

\section{THE EFFECT OF CENSORSHIP ON PUBLIC DISCOURSE DURING THE EARLY 1980S}

Any analysis of the public discourse surrounding imprisonment in South Africa during the 1980s, in particular the issue of overcrowding, must start with a consideration of the effects of the legislation which, at the time,

$2 \quad$ Prisons Act of 1959. 
restricted the media from reporting on prison conditions in the country. The legislation in question was section $44(1)(f)$ of the Prisons Act. $^{3}$ The said section reads as follows:

"Any person who publishes or causes to be published in any manner whatsoever any false information concerning the behaviour or experience in prison of any prisoner or ex-prisoner or concerning the administration of any prison, knowing the same to be false, or without taking reasonable steps to verify such information (the onus of proving that reasonable steps were taken to verify such information being upon the accused) shall be guilty of an offence and liable on conviction to a fine not exceeding two thousand rand or, in default of payment, to imprisonment for a period of not exceeding two years or to such imprisonment without the option of a fine or to both such fine and such imprisonment."

Although clearly designed to stifle discussion in the media about conditions in South African prisons, an unintended (and somewhat ironic) consequence of this measure was that the measure itself became the focus of much public discussion. Time and time again, reports in South African newspapers bemoaned the fact that reporting on conditions in South African prisons was a risky business, with section 44(1)(f) of the Prisons Act exercising a significant "chilling effect" on what they chose to publish. The negative consequences of this censorship were discussed in the media over and over again. Furthermore, when facts about conditions in any of South Africa's prisons were placed in the public arena by prison officials, or by legal order, newspapers eagerly seized the opportunity to "lift the veil" of censorship surrounding conditions in the country's prisons. This eagerness to reveal details of a world usually shrouded behind the provisions of section 44(1)(f) of the Prisons Act, seems to have lent a certain urgency, prominence and dramatic effect to media reports on prison conditions in South Africa during this period - the opposite, presumably, of what those who framed the section hoped to achieve. It may be argued, perhaps, that the relationship between censorship on the one hand and public discourse on the other ought not to be understood as fixed, immutable and onedirectional. Rather, this relationship ought to be understood as an ongoing dialectical struggle, constantly changing and evolving, as the broader battle between those forces defending the apartheid system and those opposed to it played itself out. Certainly, the many ironies associated with the censorship provisions in force during this period of the struggle were not lost on the news reporters who contributed to the public discourse surrounding South African prisons in the early 1980s. A good example is the following extract from an article which appeared in the Eastern Province Herald in July 1980, concerning certain negative comments on South African prison conditions which had been made in a report by the American State Department:

"The American State Department's report alleging maltreatment of South African prisoners is a good example of how attempts by the Government to restrict information can backfire. The report, based on allegations from unnamed sources, claims that people detained under the security laws have

3 Of 1959

$4 \quad S$ 44(1)(f) of the Prisons Act of 1959. 
been tortured. Not unexpectedly, the South African Government has denied this charge. Whether the State Department's report is true is not at issue here. The point is that no ordinary person is in a position properly to judge between the allegations and the denial. This is because the Government has made it almost impossible, under pain of severe penalties, for independent inquirers to disclose details of how prisoners are treated ... The only way to remove public suspicion is to ensure that the activities of officials are accessible to thorough public scrutiny."

During the years to come this was a point which would be made over and over again in the public media. The ideological pressure brought to bear on the prison authorities around the issue of censorship was such that, from time to time, they were pressurized into adopting a more lenient approach towards the censorship of information relating to prison conditions, in the hope of "getting the press on their side". ${ }^{6}$ This should not be taken to mean that the steps taken by the apartheid government to censor information about conditions in South African prisons were ineffective. Indeed, the "chilling effect" of section 44(1)(f) of the Prisons Act on public discourse on this topic was very real, as is apparent from public debates which took place in the early 1980s around the Steyn Commission of Enquiry into the mass media.

\section{THE STEYN COMMISSION OF ENQUIRY AND THE CHILLING EFFECT OF SECTION 44(1)(F)}

Any discussion concerning the Steyn Commission of Enquiry must take into account the political and ideological environment surrounding the mass media at the time the Commission was set up. During the late 1970s and early 1980 s, as the struggle against the apartheid regime intensified, there was increasing pressure on the Nationalist Party Government to exert even

"Promoting Rumour" 30 July 1980 Eastern Province Herald 22.

6 Eg, in June 1981 the Sunday Tribune was allowed limited access to Zonderwater Prison, which housed one thousand long-term white prisoners, in terms of a more "open" policy which had, supposedly, been adopted by the public relations section of the prison service. The novelty of being allowed some limited access to South African prisons at this time is apparent from the tone of the report by the Sunday Tribune's investigating journalist, Sanderson-Meyer: "Zonderwater is a world within the world, a world which the prison service public relations section, under its newly-proclaimed open policy, is apparently willing to unpeel layer by layer before a curious and even critical media." (See reference below.) Not too much must be made of this more "open" policy, since Sanderson-Meyer was only allowed to interview three prisoners selected by a warder. Despite this, he was able to provide readers of the Sunday Tribune with at least some insight into the seamier side of life in Zonderwater. He explained that "[t]wo of the most vicious prison murders by inmates" had occurred in that prison, and that the court hearing the matter had been given an insight into a side of prison life which included "[s]odomy, drug abuse, violence, and sudden death". (See reference below.) He further informed readers that: "One of the prisoners interviewed said homosexuality was rife, but could be avoided if one did not tangle with a 'Mr Big'. $\mathrm{He}$ said the Mr Bigs dominated prison society in the same way as did schoolboy bullies in the classroom. The ordinary prisoner had to tread a narrow path between not offending the $\mathrm{Mr}$ Bigs and the warders, although he said there was very little victimisation by the warders ..." For all quotations in this footnote see "The Dark Side of Zonderwater - Sodomy, Drugs, Violence and Murder are all part of Prison Life ... but Sometimes it's Harder on Warders than Convicts" 14 June 1981 Sunday Tribune 10. 
stricter control over an already hamstrung press. On 18 September 1979 Alwyn Schlebusch, the Minister of Justice and the Interior, proposed the establishment of a press code, to be enforced by a statutory press council. Had this proposal been adopted it would, of course, have brought the South African press under much tighter Government control, and delivered a serious blow to what remained of press freedom in South Africa at the time. It was in this context that the Government set up a commission of enquiry in June 1980 under the chairmanship of Mr Justice MT Steyn. The question which the Steyn Commission of Enquiry was asked to address was "whether the conduct of, and the handling of matters by the mass media meet the needs and interests of the South African community and the demands of the times, and, if not, how they can be improved".

For the purposes of this article, discussion will be focused on the evidence given by Benjamin Pogrund, the Deputy Editor of the Rand Daily Mail, who was particularly knowledgeable about the effects of section 44(1)(f) of the Prisons Act on the South African mass media, since he had been intimately involved in reporting on South African prison conditions for more than two decades. ${ }^{8}$ Pogrund gave his evidence in December 1980 and spoke at length about the extent to which section 44(1)(f) of the Prisons Act discouraged newspaper reporters from reporting on poor conditions within South Africa's prisons. Referring to his experiences two decades earlier as a reporter for the Rand Daily Mail, he recalled an incident which took place in 1960 , in which eighteen people had died in Modderbee Prison due to overcrowding and poor conditions. He informed the Commission that these people had died while he was conducting a lengthy and cautious investigation, since he was well aware of the severe burden placed on reporters by section 44(1)(f). He told the Commission that he "wondered then, and still wonders, if those lives might have been saved had publicity been given earlier to what was happening inside the prison". 9 Although the provision might seem reasonable on the face of it, Pogrund maintained that, in his own personal experience and in that of the South African Press as a whole, the effect of the provision had been that it had "sealed off prison conditions from the public gaze". ${ }^{10}$ Pogrund told the Commission that, during the early 1960s, he "constantly received information, especially from blacks, about poor conditions in prisons" but that he only occasionally bothered to take notes because "like every other journalist in South Africa of whom I was aware, I had come to accept that virtually nothing could be published unless it emanated from the Department of Prisons and that independent reporting was at an end". ${ }^{11}$ Pogrund then detailed events which took place in 1965, leading up to the well-known criminal case of State vs SAAN, in which he and his editor, Laurence Gandar, were prosecuted and convicted of

\footnotetext{
7 See Myburgh "The ANC, the Nats and the Free Press" 17 August $2010 \mathrm{http}: / / \mathrm{www}$. politicsweb.co.za/politicsweb/view/politicsweb/en/page71619?oid=193622\&sn=Detail (accessed 2013-11-25)

8 "Sealing off Prisons from the Public Gaze" 10 December 1980 Rand Daily Mail 16.

9 Ibid.

10 Ibid.

11 lbid.
} 
contravening section $44(1)(f)$ of the Prisons Act. $^{12}$ The matter involved a series of reports in the Rand Daily Mail on the experiences of two warders and two prisoners at Cinderella Prison, Boksburg, as well as the experiences of a former political prisoner, Harold Strachan, who had served a three-year sentence of imprisonment. Pogrund explained in moving terms what happened to him and those around him as a result to his reporting:

"To my astonishment, publication of the reports had the most extraordinary consequences. A banning order was immediately imposed on Mr Strachan ... He was prosecuted and found guilty and jailed. My other informants were also prosecuted; one was, however, acquitted. In due course, Mr Gandar and I were prosecuted under Section 44(f) and after a trial of many months were found guilty. My company was involved in the expenditure of some R300 000 . My passport was seized and I did not regain it until some five years later. We were subjected to the overwhelming might of the State, directed at disproving the reports. All the proceedings took more than four years out of my life.

Apart from describing what happened to him and those around him as a result of his reporting, Pogrund went further in providing the Steyn Commission of Enquiry with the following disturbing insight into the way in which measures such as section 44(1)(f) of the Prisons Act served to "chill" the operations of South Africa's free press, when it came to reporting on conditions within South African prisons:

"[T]he practical effect to my knowledge has been that newspapers invariably handle critical information on prisons by going to the Department of Prisons with the material and asking if it is true. Only if the department says the information is indeed correct, or else specifically agrees to publication, will the report be viewed as legally safe for publication. According to legal opinion I have had in a specific case, the department's failure to comment, or evasion of the issue, ${ }_{14}$ or use of 'no comment', are not sufficient to allow for safe publication."

Pogrund pointed out that this situation was "manifestly absurd", since it meant that the Department of Prisons could effectively control what information would appear in the Press. He made the obvious point that, where undesirable prison conditions were uncovered, it would be "expecting over-much of the human character to expect officials to own up readily, and to confirm, that abuses are taking place in areas under their control". ${ }^{15}$ The overall result, according to Pogrund, was that "remarkably little about prison conditions" appeared in the South African Press.

The chilling effect of the section 44(f) was not only wide but also deep. Pogrund pointed out that information received by a newspaper from an informant might not even be submitted to the Department of Prisons, because of fear of the possible consequences for the informant involved. Simply by publishing the information to a journalist, the informant could be laying himself open to prosecution in terms of Section 44(f). Extreme caution had to be exercised in such matters and those involved were forced to

12 State v South African Associated Newspapers Ltd 1962 (3) SA 396 (T).

13 "Sealing off Prisons from the Public Gaze" 10 December 1980 Rand Daily Mail 16.

14 Ibid.

15 lbid. 
operate in a climate of fear. Pogrund pointed out that, in the case in which he had been involved, one of the cautionary steps taken was to require informants to swear to the accuracy of their statements. Unfortunately, this eventually led to charges of perjury being brought against the informants. It turned out that even the Rand Daily Mail's legal adviser was not immune from the poisonous atmosphere created by section 44(f). As Pogrund explained:

"There was even an attempt to involve our legal adviser in criminal charges: a summons under the Prisons Act was served on Mr Stuart - at 1am! - and he was charged 'as agent and legal adviser of South African Associated Newspapers Ltd'. The charges were withdrawn only some 15 months later."

Pogrund made the important point that prisons were closed institutions and, as such, were particularly prone to abuse. This meant that they should be more open to being investigated and reported upon than most other public institutions. Because section 44(f) seemed to be designed to achieve the opposite, it amounted to "an extremely grave restriction on what should be the ability of the Press to report on matters of public concern". ${ }^{17}$

The publicity surrounding the evidence of Pogrund and others before the Steyn Commission was sufficiently damaging to the reputation of the Prisons Service to prompt the head of its information section, Colonel SP Malan, to appear before the Commission in March 1981, in order to "put the issue in perspective". ${ }^{18}$ Colonel Malan strongly denied that the Prisons Act prevented reporting about the conditions in South African prisons. In response to the contention that it was difficult for journalists to judge whether or not they had taken "reasonable" steps in terms of section 44(1)(f) of the Prisons Act to check their facts, Colonel Malan stated as follows:

"The solution is that if there is any doubt, the authorities must be approached. If (the journalist) gets no answer - 'no comment' - he may publish; if he gets a negative answer he can publish his side of the issue and in the same report the answer from the authorities. There is therefore no question of Section $44(1)(f)$ placing unreasonable restrictions on Press freedom."

Colonel Malan's claim that the Prisons Act did not restrict reporting on conditions in South African prisons was subjected to severe criticism in the media. An authority on South African press law, Mr Kelsey Stuart, told the Rand Daily Mail that, in his opinion, Colonel Malan's understanding of section 44(1)(f) was incorrect. According to Stuart: "If a newspaper publishes information which turns out to be false, it will be prosecuted whether or not it gave the version of the Prisons Department, and the onus will be on the newspaper to prove that it took reasonable steps to verify the information which it published". ${ }^{20}$

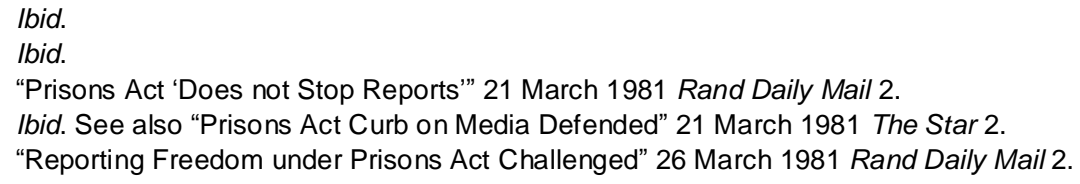


In summary it may be said that, during the period under examination, the South African public was essentially caught in a double bind in regard to both the accuracy and comprehensiveness of the information they were given about conditions in the country's prisons. On the one hand, as has been pointed out above, section 44(1)(f) of the Prisons Act certainly had a "chilling effect" on public media reporting about prison conditions. Furthermore, those reports that did appear in the public media could be skewed by sensationalist or politically biased reporting. On the other hand, the information that South Africans received from official sources at the time, such as that recorded in the annual reports of the Commissioner of Prisons, was by no means guaranteed to provide a full and fair picture of conditions in South African prisons. In February 1981, for example, a report in the Sunday Express pointed out that the previous three annual reports of the Prisons Department had made no mention of chronic accommodation shortages revealed by General Brink of the Prisons Department in evidence before the Hoexter Commission. ${ }^{21}$ According to the report, the Prisons Department admitted to this factual omission. ${ }^{22}$ Under the heading "Double Scandal" the Sunday Express made the following editorial comment, which neatly sums up the no-win situation in which South Africans found themselves when it came to information about what was really going on in the country's prisons:

"The revelations about prison overcrowding this week were shocking. What is even more shocking is that, successive annual reports by the Commissioner of Prisons made no specific reference to deteriorating conditions - and newspapers, effectively gagged by the Prisons Act, were unable properly to alert the public to an alarming situation ${ }_{33}$ But that's the price we all pay when your right to information is undermined."

Despite the caveats expressed above, particularly in relation to the public media, it is submitted that the South African press as a whole did manage to provide the public with valuable insights into what was really happening in the country's prisons in the first half of the 1980s. A close examination of the main South African newspapers during the period 1980 to 1984 reveals a rich series of debates on the issue of prison overcrowding, and it is to these debates that we now turn.

\section{THE "LIFTING OF THE VEIL" BY THE HOEXTER COMMISSION AND THE EXPLOSION OF PUBLIC DEBATE ON PRISON OVERCROWDING}

From the very start of the 1980s, the issue of prison overcrowding was in the public eye. On 12 May 1980, for example, the Minister of Prisons, Mr Louis le Grange, stated in parliament that overcrowding in South African prisons was of concern and was receiving attention at the highest level. ${ }^{24}$ It was

21 This evidence is discussed in detail in the next section of this article.

22 "Last 3 Prison Reports didn't mention the Crisis in Jails" 8 February 1981 Sunday Express 8.

23 "Double Scandal" 8 February 1981 Sunday Express 8.

24 "Vol Tronke Wek nou Kommer" 13 May 1980 Die Burger 11. 
early the following year, however, that debate on the issue really exploded in the public media. This came about due to a somewhat fortuitous turn of events. In February 1981, evidence was being heard by the Hoexter Commission, which had been appointed to investigate the structure and functioning of South Africa's courts. When the Chief Deputy Commissioner of Prisons, General Brink, appeared before the commission on 4 February 1981, he asked that his evidence be heard in camera. The chairperson of the Commission, Judge Hoexter, refused this request, effectively "neutralizing" the usual "chilling effect" of section 44(f) of the Prisons Act. The result was that, when General Brink gave evidence detailing, inter alia, the badly overcrowded state of many of South Africa's prisons, the media were free to report on the facts disclosed. The following sample of just some of the headlines to the many reports on this issue, in a wide variety of newspapers, illustrates the fact that the press made full use of the opportunity to reveal the shocking state of overcrowding in many prisons. For the sake of accuracy, the headlines which appeared in Afrikaans language newspapers are reflected as they appeared, followed by an English translation in square brackets:

"Krisis in tronke gaan kom" ["A crisis in prisons is looming"] 25

"Crisis in our prisons must be resolved"

"Vol tronke" ["Full prisons"]

"Prison overcrowding: Govt must act now"28

"Tronke in SA oorvol, getuig general" ["Prisons in SA overcrowded, according

to general's evidence"]

"House full"

"Overhaul our jail system,"31

"The prisons crisis"

"Skokfeite oor SA se oorvol tronke" ["Shocking facts about South Africa's overcrowded prisons"] ${ }^{33}$

"Disturbing glimpse behind prison walls"34

"Gevangenisse loop oor" ["Prisons overflow"] ${ }^{35}$

"Prison crisis looming"

"Oorbevolkte tronke" ["Overcrowded prisons"] ${ }_{38}^{37}$

"Concern over extent of prison overpopulation",38

"Prison time bomb"

"Prison's crisis"

\footnotetext{
4 February 1981 Die Volksblad 2.

5 February 1981 Pretoria News 20.

5 February 1981 Hoofstad 14.

5 February 1981 Evening Post 6

5 February 1981 Oggendblad 5.

5 February 1981 The Daily News 18.

5 February 1981 Sunday Tribune 22

5 February 1981 The Argus 18.

5 February 1981 Die Burger 3.

5 February 1981 The Star 20

6 February 1981 Die Burger 12.

6 February 1981 The Natal Witness 10.

6 February 1981 Die Vaderland 10

6 February 1981 The Sowetan 1

6 February 1981 The Natal Mercury.

406 February 1981 Rand Daily Mail 14.
} 
"Oorvol gevangenisse" ["Overcrowded prisons"]

"Pass laws a key to dangerously overcrowded cells" 42

"Last 3 prison reports didn't mention the crisis in jails"

"Getting to grips with the prisons' crisis"

"The problem of full prisons"

"We tried to tell you".

The cause of this media frenzy was the fact that, according to the evidence of General Brink referred to above, South Africa's prisons were approximately $40 \%$ overcrowded. In the case of black, Indian and coloured prisoners, the rate of overcrowding was even worse, standing at $59 \%$. Whereas South Africa's prisons had been built to house approximately 70,000 prisoners in total, approximately 102,000 prisoners were being accommodated in the prisons on a daily basis. ${ }^{47}$ According to the general, the overcrowding resulted in prisoners being left idle and unproductive in their cells, which increased the danger of unrest and gang warfare. The general also warned that antiquated prisons, which had been built between ninety and a hundred years previously, were neither safe nor hygienic. There was an increased risk of epidemics and General Brink warned that South Africa would have to make a super-human effort in order to avoid a crisis in its prisons. ${ }^{48}$

One of the major themes to emerge in the public discourse surrounding General Brink's evidence to the Hoexter Commission concerned the issue of censorship and the fact that the commission had lifted a "veil of secrecy" which usually obscured the realities of South African prison life from public view. Various newspaper reports pointed to the fact that the glimpse they were able to provide of the true state of affairs in South Africa's prisons at this time was thanks to the actions of Judge Hoexter in refusing to allow the evidence of General Brink to be heard in camera. Time and again, reporters and editors took the opportunity to criticize severely the manner in which reporting on conditions in South African prisons was generally restricted. For example the Rand Daily Mail spoke of the "heavy and expensive punishment" which it had suffered many years before when it tried to report on undesirable conditions in South African prisons, and stated that it was to the credit of the Hoexter Commission that General Brink's evidence was

\footnotetext{
6 February 1981 Die Oosterlig 8.

8 February 1981 Sunday Express 21.

8 February 1981 Sunday Express 8.

9 February 1981 Rand Daily Mail 6.

10 February 1981 The Friend 8.

12 February 1981 Rand Daily Mail 8.
}

47 In response to the statistics provided by General Brink, the Rand Daily Mail was prompted to ask the following difficult questions: "What unspeakable conditions of misery lie behind those statistics? And what bungling is responsible for allowing such a parlous and dangerous situation to develop over the years? To which much be added this Government's specific responsibility in creating laws which land so many people in jail unnecessarily." See "Prisons' Crisis" 6 February 1981 Rand Daily Mail 14.

48 "Krisis in Tronke gaan kom" 4 February 1981 Die Volksblad 2; "Crisis in our Prisons must be Resolved" 5 February 1981 Pretoria News 20; and "Skokfeite oor SA se Oorvol Tronke" 5 February 1981 Die Burger 3. 
heard in open session. ${ }^{49}$ In a subsequent editorial, the newspaper expressed the following opinion:

"There is no reason why jails should be sealed off, and every reason for them not to be. If anyone has had any doubt about this, then the sudden disclosure of the alarming state of the prisons should dispel it. Had it been easier for the Press to probe the prisons, the crisis situation we now have would surely have been made public long before, allowing pressure for improvement to take place.

The extent of the chink in the armour of the apartheid-penal system opened up by the Hoexter Commission should not be over-estimated. A few days after the report quoted above, the Rand Daily Mail asked the Prisons Department for permission to visit various prisons in the Transvaal for the purpose of reporting on overcrowding within those prisons, but his request was refused. ${ }^{51}$ Under the heading "We tried to tell you", the newspaper commented bitterly as follows:

"Well, we tried. When no less a person that the Deputy Chief Commissioner of Prisons, Lieutenant-General MCP Brink, disclosed - unwillingly - the crisis of overcrowding in jails, we applied to send in reporters and photographers. We wanted to tell the public what the overcrowding means in practice. The Department of Prisons has refused our request. Its reasons ... are not reasons. They are evasions. The Department of Prisons is using its power of control to conceal whatever is going on behind the high walls. Worse still, Section 44(f) of the Prisons Act, with its pervasive effects in preventing proper investigation and reporting of jail conditions, ensures that little, if anything at all, will now come to light. Any department of government which has allowed such gross overcrowding to develop ... is clearly bungling its responsibilities. How fortunate for the Prisons Department that it can hide behind restrictive laws. But how tragic for the public good - and for the prisoners crammed into their cells.'

Another newspaper to speak out against the restrictions surrounding press reporting on conditions in South African prisons at this time was the Pretoria News. After outlining the disturbing facts revealed by General Brink surrounding overcrowding in the prisons, the newspaper stated inter alia as follows:

"These are disturbing facts, made more so because the Prisons Act has clamped an iron curtain of secrecy over any and all reports of conditions in our jails. That curtain was only lifted yesterday because the commission chairman refused an application for General Brink to give his evidence in camera. His ruling did the nation a considerable service. It is high time the shortcomings of our system were exposed and the potentially explosive situation that has grown up around it was defused."

Another example of the weight of critical opinion within the press at this time against the restrictions imposed on reporting about conditions in South African prisons is to be found in an editorial in The Star. Under the headline

\footnotetext{
"Prisons' Crisis" 6 February 1981 Rand Daily Mail 14.

"Getting to Grips with the Prisons Crisis" 9 February 1981 Rand Daily Mail 6.

"'Mail' Refused permission to visit Prisons" 11 February 1981 Rand Daily Mail 2.

"We Tried to Tell You" 12 February 1981 Rand Daily Mail 8.

"Crisis in our Prisons must be Resolved" 5 February 1981 Pretoria News 20.
} 
"Disturbing glimpse behind prison walls" the editorial began and ended as follows:

"Because of the iron curtain of secrecy imposed by the Prisons Act, South Africans are rarely afforded an in-depth glimpse of conditions inside the country's jails. Yesterday there was an exception ... There is plenty of food for thought in what the deputy commissioner had to say yesterday. Not least it should give pause to reappraise the Prisons Act, which stifles any regular flow of information on a subject about which the public has every right to be concerned."

Yet another example comes from an editorial in The Natal Witness which stated, inter alia, as follows:

"Since a court case against a newspaper more than a decade ago, South Africa's prisons have to all intents and purposes been off limits to the Press. This is no doubt one of the factors which have contributed to the current crisis in our prisons. Fortified by the law against public scrutiny and criticism, the authorities have allowed the situation in our prisons to deteriorate to the alarming extent revealed to the Hoexter Commission by the Chief Deputy Commissioner of Prisons, General M.C.P. Brink."

With the above examples all being drawn from English-language newspapers, it is important to note that opposition to restrictions on reporting about conditions in South African prisons was not restricted to what may be termed, perhaps, the "English liberal press". Certain Afrikaans-language newspapers were also roundly critical of the general secrecy surrounding prison conditions in South Africa at this time, as well as the de facto censorship of open and honest reporting on these conditions. A good example is the following extract from a report in the Afrikaans-language newspaper Rapport:

"Full points to judge Hoexter, who decided this week that shocking evidence about South Africa's overcrowded prisons must be given in public ... The overcrowded state of our prisons is a scandal. And what makes it even more scandalous is the fact that the Viljoen Commission made recommendations concerning the same problem in 1976 and that the implementation of those recommendations is still being hampered. And then this week General M.C. Brink has the audacity to attempt to have his evidence before the Hoexter Commisssion concerning this same problem heard in secret. It drives one to tears."

Another example of disapproval within the Afrikaans-language press of the restrictions around reporting on conditions in South African prisons at

54 "Disturbing Glimpse behind Prison Walls" 5 February 1981 The Star 20.

55 "Prison Crisis Looming" 6 February 1981 The Natal Witness 10.

56 "'n Volle punt aan regter Hoexter, wat die week beslis het dat die skokkende getuienis oor Suid-Afrika se oorvol tronke in die openbaar gelewer moet word ... Dis 'n skande dat dit so in ons tronke gaan. En wat die skande nog erger maak, is dat die Viljoen-kommissie al in 1976 aanbevelings oor dieselfde problem gedoen het en dat daar nou nog gesloer word met die uitvoering van daardie aanbevelinge. En dié week wend genl. M. C. Brink jou waarlik 'n poging aan om sy getuienis oor dieselfde ou problem in die geheim voor die Hoexter-kommissie te lewer. Dis om van te huil." See "Volle Punt, Regter H!" 8 February 1981 Rapport 18. 
this time is to be found in the following extract from an editorial in the newspaper Beeld:

"A final thought is that the Prisons Act would have prevented or made it
difficult for the press to reveal these conditions to the world. Hopefully
changes can also be made in that regard. It is only by revealing the existence
of poor conditions that society may be mobilised to make its contribution,
through its ${ }_{\text {, }}$ ideas and deeds, to ensuring transparent and clean
governance."

Stating that it was time to seriously reconsider the restrictions on reporting about prison conditions in South Africa, Rapport expressed the opinion that, in the long run, there were more advantages than disadvantages to greater openness.

From the above, it would seem clear that more than ten years before the official demise of the apartheid system, the tide of public opinion (at least as seen through the lens of the mainstream media) was turning against the apartheid regime on the issue of censorship, in particular when it came to details about the deteriorating conditions in South Africa's prisons.

\section{THE WRITING ON THE WALL? PUBLIC DISCOURSE, PRISON OVERCROWDING AND THE APARTHEID SYSTEM OF SOCIAL CONTROL}

A second major theme which emerged from the public discourse around General Brink's evidence to the Hoexter Commission, was the commonly expressed view that much of the chronic overcrowding in South Africa's prisons was due to the fact that the prisons were being used to enforce ideologically driven policies of "social control". This meant that, in addition to accommodating a large number of convicted criminals, South African prisons were forced to accommodate thousands of ordinary citizens whose only "crime" was to have fallen foul of one or other of the social-control measures (such as the notorious "pass laws") put in place by the apartheid regime. These social-control measures were designed to prevent "non-white" citizens from moving freely about the country, potentially "flooding" (so the apartheid logic went) those areas reserved for "whites".

The public discourse around General Brink's evidence to the Hoexter Commission makes it clear that, by the early 1980s, most thinking South Africans were fully aware of the fact that using imprisonment as a method of enforcing "social control" was not only morally unacceptable, but gave rise to a host of social problems. Foremost among these problems was fact that it contributed to the chronic overcrowding in South Africa's prisons, with all the

\footnotetext{
57 "' $n$ Laaste gedagte is dat die Gevangeniswet die pers sou gekeer het of dit sou bemoeilik het om die soort toestande wereldkundig te maak. Ook daarin kan hopelik veranderinge aangebring word. Alleen deur verkeerde toestande te openbaar, kan die gemeenskap gemobiliseer word om deur denke en dade ook sy bydrae te lewer ten einde oop en skoon landsadministrasie te verseker." See "Gevangenis-les" 6 February 1981 Beeld 8.

58 "Tronke" 8 February 1981 Rapport 18.
} 
negative consequences for the day-to-day lives of prisoners. ${ }^{59}$ From the start, it was clear to all concerned that the scale of the problem was so great that it could not be solved by simply building more prisons. ${ }^{60}$ In responding to the evidence of General Brink on the extent of overcrowding in South Africa's prisons, the Minister of Justice, Mr Kobie Coetzee, admitted to the press that the problem could not be solved simply through the provision of additional prison accommodation. He stated that methods would have to be found to reduce the flow of offenders into prisons. ${ }^{61}$

The debates which took place in the national newspapers following General Brink's revelations to the Hoexter Commission, indicate that most informed commentators at that time had come to believe that the continued use of imprisonment as a means of enforcing apartheid social-control legislation was no longer sustainable. Over and over again, commentators in the public media pointed out that South Africa's prisons were filled with ordinary citizens who had fallen foul of apartheid laws designed to control the black population. It is worth quoting The Sowetan at some length on this point:

"Last week's revelations of overcrowding in South African jails came as no surprise to us and a great number of blacks who have had the misfortune of falling foul of the law. Being black in itself can make sure that you get a taste of jail. The reason is not difficult to find: Thousands of people are daily being arrested and locked up for what are in fact technical offences related to the pass laws. We know the majority of those people who are forced to populate our jails are not criminals ... So what do they want in those jails? The answer is simple: All they wanted to do was find employment that would bring them the income they so desperately want and need to keep the home fires burning. All they want to do is sell their labour to the highest bidder. After all, South African is a capitalist country. Is it not? Yet, those people are made instant criminals simply because of some endorsement or other in their pass book. The Government prescribes to them whether they can, or cannot, live or work in certain areas ... [T]he general public, particularly whites, never fully

59 It should be noted that is was not only the prisoners who suffered due to overcrowding. One of the consequences of chronic overcrowding was a drastic shortage of prison personnel, and it was reported that there was a shortage of 5000 "white" and 5000 "non-white" prisonstaff members. According to the evidence of General Brink before the Hoexter Commission, the R49,000,000 which it would cost to employ these extra staff members was simply not available. Furthermore, the Department of Prisons was already finding it difficult to attract suitable persons to join the Department. The General even went so far as to state that he did not get the impression that people (young white men) were joining the department in order to avoid their (compulsory) military service. See "Tronke in SA Oorvol, Getuig Generaal" 5 February 1981 Oggendblad 5.

60 It is interesting to note that authorities in the post-apartheid period would reach a similar conclusion, after realizing that the cost of building the extra accommodation needed to solve the problem would be prohibitive, and rejecting several bizarre schemes which proposed making use of disused mine shafts or de-commissioned ships to accommodate South Africa's burgeoning prison population! See in general, Peté "The Politics of Imprisonment in the Aftermath of South Africa's First Democratic Election" 19981 South African Journal of Criminal Justice 51-83; Peté "The Good the Bad and the Warehoused - The Politics of Imprisonment During the Run-up to South Africa's Second Democratic Election" 2000 13(1) South African Journal of Criminal Justice 1-56; and Peté "Between the Devil and the Deep Blue Sea - The Spectre of Crime and Prison Overcrowding in Post-apartheid South Africa" 200627 (3) Obiter 429-453.

61 "Minister oor Oorval Tronke" 6 February 1981 Die Burger 11. 
appreciate the problems that people face when going to jail, or the extent and impact of such jailings."

The Sowetan was not alone in its condemnation of the apartheid regime and its laws. The Pretoria News pointed out that apartheid had "made statutory criminals of too many people" and stated that this had "overburdened and slowed down the administration of justice and swollen our jails to a dangerous degree". ${ }^{63}$ The Argus stated that the effect of the apartheid social-control laws was to "manufacture prisoners from a generally respectable population" and to "make criminals of tens of thousands of decent South Africans". ${ }^{64}$ Calling the evidence given by General Brink a "shocking indictment of the overcrowded conditions in South African prisons", an editorial in the Evening Post called for the practice of "sending blacks to prison for minor technical offences under the pass laws" to be stopped. ${ }^{65}$ The Eastern Province Herald called the pass law system enforced by the apartheid regime "unique to South Africa in the Western world" and pointed out that:

"Laws based solely on skin colour and stipulating where a person may live, move or work can make of a black man a criminal within minutes. These laws, lacking any moral force and bitterly resented by blacks, are one of the worst manifestations of apartheid." 66

The Herald quoted a spokesperson for the Black Sash, Mrs Val Oertel, who condemned the apartheid social-control measures as "a feudal system inappropriate to the 20th century" and stated that it was "a scandal that human beings should be imprisoned in the land of their birth for contraventions of laws imposed on them by a Government which they did not vote for". ${ }^{67}$ The Herald further called for the pass laws and related regulations to be scrapped, stating that: "Perhaps then South Africa would not have 440 of every 100000 of its people in prison each year - a rate more than double that of any other country in the West." ${ }^{, 68}$

Within the "liberal" press, there was a clear understanding that the legal and structural edifice put in place by the apartheid regime in order to control the movement of "non-white" South Africans, was built on sand. It was clear to the majority of commentators that the system was not sustainable in the long term, not only because it was morally reprehensible, but because it was prohibitively expensive. The Sunday Tribune was one of the newspapers which pointed to the crippling cost, both financial and moral, of implementing the social-control measures put in place by the apartheid regime:

"It is estimated that in the decade 1965 to 1975 there were more than six million prosecutions under the pass laws. The cost of prosecution and

\footnotetext{
"Why Jail People who are not Criminals?" 5 February 1981 The Sowetan 6.

"Crisis in our Prisons must be Resolved" 5 February 1981 Pretoria News 20.

"The Prisons Crisis" 5 February 1981 The Argus 18.

"Prison Overcrowding: Govt must Act Now" 5 February 1981 Evening Post 6.

"System that Clogs the Prisons" 6 February 1981 Eastern Province Herald 12.

"Call on Use of Aid Centres Welcomed" 6 February 1981 Eastern Province Herald 4.

68 "System that Clogs the Prisons" 6 February 1981 Eastern Province Herald 12.
} 
imprisonment was R200-million and the cost of policing and patrolling more than R100 000000 . No other country in the world has to bear such a crippling burden of expenditure to maintain what are blatently discriminatory laws ... It is inconceivable that in the year 1981 we are trying to maintain a system of population control that just will not work any more. What is more it fills with deep resentment the majority of people, and it helps to intensify a dangerous world hostility. Lastly, but by no means least, it gives many blacks a contempt for these particular laws, and an acceptance of imprisonment as an inevitable feature of black life. In some it generates a contempt for all law and order. We are dealing here with a social problem of the gravest kind."

The Tribune made it clear that any attempt to "repair and strengthen the existing machinery" would be futile, and recommended a complete overhaul of the system, large parts of which should be "permanently dismantled". ${ }^{70}$ Similar sentiments were expressed by the editor of The Natal Witness, who insisted in a perceptive editorial that merely tweaking the apartheid system of social control would not work:

"As long as Blacks can be sent to jail in their thousands for technical offences under the pass laws, our prisons will continue to be over-populated. To streamline procedures, expand prisons, and employ more warders is to address the symptoms of the problem, but not the underlying causes."

The press also reported on calls by the Progressive Federal Party, the official parliamentary opposition at the time, that the apartheid social-control legislation be scrapped. Mrs Helen Suzman, the opposition's chief spokesperson on justice, pointed out that more than 700,000 people had been imprisoned for pass offences between 1977 and 1979, and that 15,000 people had been imprisoned for curfew violations in 1980, and she called for these laws to be changed. ${ }^{72}$ Mrs Suzman castigated the apartheid authorities for failing to address the problem of overcrowding and stated that:

"I have been pointing to the problem for a long time. They appear to have been unconcerned for years over the bad over-crowding - which is a result of the high number of statutory offenders. We don't need more prisons, we need to change the laws."

The opinions of "experts" were also harnessed in support of the call for the apartheid social-control regulations to be scrapped. For example, pointing out that over 300,000 black South Africans were arrested annually for offences under influx laws, Professor Marinus Wiechers, then head of Constitutional Law at the University of South Africa, was quoted as stating that: "The moral of this sad story ... is quite simple: you cannot regulate socio-economic matters by making them crimes." ${ }^{74}$

\footnotetext{
"Overhaul our Jail System" 5 February 1981 Sunday Tribune 22.

Ibid.

"Prison Crisis Looming" 6 February 1981 The Natal Witness 10.

"Prisons: Act Now, Govt Urged" 5 February 1981 The Argus 4.

"Last 3 Prison Reports didn't Mention the Crisis in Jails" 8 February 1981 Sunday Express 8.

74 "Pass Laws a Key to Dangerously Overcrowded Cells" 8 February 1981 Sunday Express 21.
} 
Most but not all the commentary in the press at this time supported the scrapping of the social-control measures that had been put in place by the apartheid regime. Certain commentators, particularly in certain sections of the Afrikaans Press, seemed to believe that it might be possible to fine-tune the support mechanisms which underpinned the apartheid social-control measures, so as to take the pressure off the prisons. For example, Oggendblad spoke of the need for the "advice centres" run by the Department of Co-operation and Development, as well as certain courts, to operate during the night as well as during the day. Apparently hoping for a way out of the administrative quagmire created by the apartheid system, without having to scrap the entire edifice, the newspaper stated that it was thinking "particularly of black people who have problems relating to their documentation, reporting at labour bureaus, residential permits, pass-law offences and so on, who can be assisted easily at advice centres and possibly never have to come near a prison if timeous attention is given to their problems". ${ }^{75}$ These words hint at the administrative nightmare in which the majority of South Africans were enmeshed at this time of the country's history.

One of the more subtle arguments which was put forward in opposition to the idea that apartheid social-control legislation should simply be scrapped, was to acknowledge that the apartheid social-control measures were a significant factor contributing to overcrowding in South African prisons, but to argue that the repeal of these measures would lead to even more serious problems. Such arguments were, once again, raised mainly in certain sections of the Afrikaans press. For example, the Afrikaans-language newspaper Hoofstad commented as follows on the evidence of General Brink to the Hoexter Commission:

"One of the factors which he identified for this unhealthy state of affairs [ie, the overcrowding] is the detention of black people for technical offences, inter alia as a result of social control measures. It would be shortsighted to claim that the problem can be solved by revoking these social control measures. Indeed, we believe that this would create conditions that would lead to many more serious problems."

75 "Hier word veral gedink aan swart mense wat probleme met dokumente, aanmelding by arbeidsburo's, losiespermitte, bewysboekoortredings en dies meer het, wat maklik by hulpsentrums van raad bedien kan word en moontlik nooit eens naby 'n gevangenis hoef to kom indien daar betyds aan hulle probleme aandag gegee kan word nie." See "Tronke in SA Oorvol, Getuig Generaal" 5 February 1981 Oggendblad 5.

76 "Een van die faktore wat deur hom uitgesonder word vir die ongesonde toedrag van sake [ie, the overcrowding], is die opsluiting van swartmense weens tegniese oortredings, onder meer ingevolge instromingsbeheermaatreels. Nou is dit 'n kortsigtige siening om te beweer dat die probleem opgelos sal word deur die opheffing van dergelike beheermaatreels. Trouens, ons glo dat juis daardeur omstandighede geskep kan word wat sal lei tot veel ernstiger probleme." See "Vol Tronke" 5 February 1981 Hoofstad 14. 
Die Oosterlig expressed a similar view, stating that:

"Revoking influx control could lead to indescribable problems in providing housing, and the labour market in cities would be swamped with people seeking employment who could not be accommodated."

For its part, the apartheid government was certainly not ready to simply abandon the social-control measures that it had put in place over many years. In his response to the furore over prison overcrowding, the Minister of Justice, Mr Kobie Coetzee, pointed out that, whereas social-control offenders had made up 32,5 percent of the South African prison population during the period 1 July 1978 to 30 June 1979, this percentage had subsequently dropped to 24 percent. $^{78}$ The Rand Daily Mail responded to these statistics provided by the Minister by stating that: "Either way, it is unacceptable, and is making criminals out of ordinary people whose 'crime' is that they are desperately trying to find jobs to earn money for survival."79 Whether or not the Minister fully appreciated the Mail's point that the apartheid government's position on this issue was morally untenable, it must have been clear to him that the long-term stability of the prison system (and, indeed, the apartheid system itself) was under serious threat. Faced with the intractable problem of prison overcrowding, and ideologically unable to reconcile his Government to admitting and addressing the deep political injustices and economic imbalances which caused the problem, the Minister's response was to prevaricate and suggest stopgap solutions. While assuring the public that the Government was paying serious attention to the problem, the actual steps he proposed taking indicated that the apartheid Government had no real idea how this problem was going to be solved. The best the Minister could do was to inform the press that a departmental seminar would be held in the near future in order to discuss the problem of prison overcrowding, and that he had decided to set up a working group which would investigate possible solutions to the problem. ${ }^{80}$ The Minister also told the press that he would recommend to Cabinet that certain prisoners should be granted amnesty "on the occasion of the coming Republic Festival". ${ }^{81}$ The proposal that prisoners be granted amnesty in order to relieve pressure on the system is indicative of the strain on the apartheid penal system at the time, as well as the absence of any proper plan to deal with the problem. It should be noted at this point that the granting of amnesty to certain categories of prisoners as a means of relieving the pressure created by chronic overcrowding, was not only used during the apartheid period, but also became an enduring theme of the postapartheid period, when the practice became known as "bursting". ${ }^{2}$ This

77 "[O]m ... instromingsbeheer af te skaf, kan onbeskryflike probleme met huisvesting veroorsaak en die arbeidsmark in die stede sal toegegooi word met werksoekers wat net nie geakkommodeer sal kan word nie." See "Oorvol Gevangenisse" 6 February 1981 Die Oosterlig 8.

78 "Minister oor Oorvol Tronke" 6 February 1981 Die Burger 11.

79 "Getting to Grips with the Prison Crisis" 9 February 1981 Rand Daily Mail 6.

80 "Minister oor Oorvol Tronke" 6 February 1981 Die Burger 11.

816 February 1981 The Cape Times 4.

82 See in general, Peté 19981 South African Journal of Criminal Justice 51-83; Peté 2000 13(1) South African Journal of Criminal Justice 1-56; and Peté 2006 27(3) Obiter 429-453. 
clearly indicates that the problem of prison overcrowding is much more deeply entrenched than many commentators over the years have been prepared to admit.

The fact that many of the deep social and economic roots of South Africa's problem of prison overcrowding would remain after the abolition of the apartheid social-control regulations was appreciated by certain commentators in the early 1980 s, even though the apartheid system was to endure for more than a decade after this period. As pointed out above, certain commentators, particularly on the right of the political spectrum, did warn that the abolition of measures such as influx control would lead to serious social problems. On the left of the political spectrum, there were also commentators who appreciated that prison overcrowding in South Africa was a deep-rooted economic and social problem, which would not be easy to remedy. For example, at the time of the debate over General Brink's evidence to the Hoexter Commission, an editorial in The Daily News stated as follows:

"A combination of poverty and numerous technical offences are saddling

prisons with large numbers of people who should not be there in the first

place. The problem is not in the prisons, it lies outside in our society and the

laws that govern it."

In concluding this section, it is worth emphasizing the point that the demise of apartheid, together with its reprehensible measures of social control, did not mark the end of chronic overcrowding in South Africa's prisons. As has been documented elsewhere, imprisonment during the postapartheid period was, for many years, characterized by chronic overcrowding, despite the repeal of social-control measures. ${ }^{84}$ Indeed, as this article is being written in 2013, chronic overcrowding remains the single most serious problem confronting the Department of Correctional Services in South Africa. This is well illustrated by the reported comments of the Minister of Correctional Services, Sbu Ndebele, at a meeting with senior leadership of the Police and Prisons Civil Rights Union and the Public Servants Association of South Africa in February 2013. The Minister was reported as stating that South Africa had the highest prison population in Africa and that the country was "currently ranked ninth in the world in terms of prison population, with approximately 160000 inmates". ${ }^{85}$ From the perspective of this article, looking at the present through the lens of debates which took place in the early 1980s, it is interesting to reflect upon the following further comment of the Minister: "That our offender population has remained constant, whether you remove pass laws, group areas, or apartheid laws, should make us search more urgently for answers to the high prison population in South Africa." ${ }^{86}$ Clearly, the post-apartheid experience has

83 "House Full" 5 February 1981 The Daily News 18; and see also "The Problem of Full Prisons" 10 February 1981 The Friend 8.

84 See in general, Peté 19981 South African Journal of Criminal Justice 51-83; Peté 2000 13(1) South African Journal of Criminal Justice 1-56; and Peté 2006 27(3) Obiter 429-453.

85 See http://mg.co.za/article/2013-02-11-south-africa-has-highest-prison-population-in-africasays-ndebele Mail \& Guardian Online (accessed 2013-02-12).

86 Ibid. 
revealed that the problem of prison overcrowding in South Africa is a much more deeply rooted economic and social problem than may have been believed by many commentators over the years.

\section{CONCLUSION}

In part one of this article it has been argued that public debates which took place during the early 1980s in South Africa on the issue of prison overcrowding are relevant in a number of respects. In the first place, debates around the issue provided a platform for a wide range of commentators to express concern about the dangers of censorship and the extremely negative consequences of legislation designed to restrict the free reporting of information on crucial social and political issues, such as the conditions in the country's prisons. Furthermore, despite the legislative restrictions which were in place during the early 1980s preventing open reporting about conditions in South African prisons, a close examination of the public discourse during this period reveals a rich series of debates on the issue of chronic overcrowding. Of particular interest is the fact that these debates were inextricably linked to debates on the viability of the apartheid system itself, in particular the measures of social control which had been put in place by the apartheid regime. It is submitted that these debates acted as a mirror to ordinary South Africans, particularly white middle-class South Africans who were the beneficiaries of the apartheid system, revealing to them the moral bankruptcy of the system, as well as the fact that it was impractical and untenable in the medium to long term. For those prepared to look beyond the political realities of the time, as crucially important as they were, the debates also revealed a deeper truth, relevant to imprisonment as a form of punishment in South Africa across decades and even centuries. This is the fact that chronic overcrowding seems to be inextricably, perhaps even structurally, linked to this form of punishment, and that the same "solutions" are recycled year after year, decade after decade, and even from one century to the next. Part two of this article will take forward these and other themes as revealed in the public debates around prison overcrowding in South Africa during the first half of the 1980s. 